\section{Paloma O Shea Santander International Piano Competition}

Calle Hernán Cortés 3, E-39003 Santander, Spain.

Tel: $\quad$ (34) 942311451

Email: concurso@albeniz.com

Website: www.concursodepianodesantander.com/

Contact: A Kaufmann, Secretariat General

The Paloma O'Shea Santander International Piano Competition is one of the best rated competitions in the world. It provides an opportunity for exceptionally talented pianists to enhance their careers. The jury is composed of renowned musicians in order to ensure that grants are made in a fair and unbiased manner.

\section{Gold, Silver and Bronze Medals}

Subjects: Musical instrument (piano)

Purpose: To give support to young planists of Exceptional talents

Eligibility: Competition is open to all pianists born on 1st January, 1994 and after

Level of Study: Unrestricted

Type: Other

Value: Cash prizes totalling more than $€ 90,000$

Frequency: Varies

Study Establishment: ANY

Country of Study: Any country

Application Procedure: Online application for the 2022 competition www.santanderpianocompetition.com available from June

No. of awards offered: 7

Closing Date: November

Funding: Government, Commercial, Private, Foundation

(C) Springer Nature Limited 2020

Palgrave Macmillan (ed.), The Grants Register 2021,

https://doi.org/10.1057/978-1-349-95988-4
No. of applicants last year: 241

Additional Information: Cash prizes totalling more than $€ 90,000$; concerts in Spain and abroad; CD recording; online promotion campaign

\section{For further information contact:}

Calle Luis Martínez, 21, E-39005 Santander, Cantabria, Spain.

Tel: (34) 942311451

\section{Paralyzed Veterans of America (PVA)}

801, 18th Street NW, Washington, DC 20006-3517, United States of America.

Tel: (1) 8005559140

Email: info@pva.org

Website: www.pva.org

The Paralyzed Veterans of America (PVA), a congressionally chartered veterans service organization founded in 1946, has developed a unique expertise on a wide variety of issues involving the special needs of the members-veterans of the armed forces who have experienced spinal cord injury or dysfunction.

\section{Paralyzed Veterans of America Fellowships in Spinal Cord Injury Research}

Purpose: To provide support for research done in the United States or Canadian laboratories and improve the quality of life for individuals with spinal cord injury and spinal cord dysfunction and to find an eventual cure for paralysis 
Eligibility: Open to citizens of the United States

Level of Study: Postgraduate, Research

Type: Fellowship

Value: US $\$ 50,000$

Frequency: Annual

Country of Study: United States of America

Application Procedure: Applicants must submit curriculum vitae and 10 copies of grant application. Application form, reference letters and budget are required

Closing Date: 1 April

Additional Information: pva.org/research-resources/ research-foundation/

\section{For further information contact:}

Tel: $\quad$ (1) 2024167611

Email: LindsayP@pva.org

\section{Parapsychology Foundation, Inc.}

PO Box 1562, New York, NY 10021-0043, United States of America.

Tel: $\quad$ (1) 2126281550

Email: $\quad$ office@parapsychology.org

Website: www.parapsychology.org

Contact: Vice President

Established in 1951, the Parapsychology Foundation acts as a clearing house for information about parapsychology. Essentially an administrative organization, it maintains one of the largest libraries to do with parapsychology, the Eileen J Garret Library, as well as supporting various programmes that include the library, a grant and scholarship programme, a conference and lecture programme, and a speaker's bureau and publishing programme.

\section{Eileen J Garrett Scholarship}

Purpose: To assist students attending an accredited college or university in pursuing the academic study of the science of parapsychology

Eligibility: 1. Must be an undergraduate student, a graduate student or a postgraduate student. 2. Must attend a university, a four-year college or two-year college. 3. Citizenship requirements: US. 4. Must not be attending high school currently. 5. Must study full-time. 6. Restricted to students studying Social Sciences.
Level of Study: Unrestricted

Type: Scholarship

Value: US $\$ 3,000$

Length of Study: 1 year

Frequency: Annual

Study Establishment: An accredited college or university

Country of Study: Any country

Application Procedure: Applicants must submit samples of writings on the subject with an application form from the Foundation. Letters of reference are required from three individuals, familiar with the applicant's work and/or studies in parapsychology

Closing Date: 15 July

Additional Information: www.petersons.com/scholarship/ eileen-j-garrett-scholarship-for-parapsychological-research111 150558.aspx

\section{For further information contact:}

PO Box 1562, New York, NY 10021-0043, United States of America.

Tel: (1) 2126281550

Fax: (1) 2126281559

\section{Paris School of International Affairs (PSIA)}

27, Rue Saint-Guillaume, F-75007 Paris, France.

Tel: (33) 145495050

Website: www.sciencespo.fr/psia/

In keeping with Sciences Po's centennial tradition of excellence, PSIA offers a cutting-edge education to tomorrow's leaders in international affairs. With 1,300 students coming from 100 countries, taught by world-renowned professors and practitioners, PSIA rises as a vibrant global pulse in Europe and a primary platform for global debate, rooted in the academy.

\section{Kuwait Program at Sciences Po Excellence Scholarship for Arab Students and Kuwait Nationals}

Purpose: The Kuwait Program at Sciences Po offers excellence scholarships to students with an interest in the Middle 
East who are admitted to PSIA for the current year intake on the programs listed at the website

Eligibility: These scholarships are awarded on a competitive basis, based on the candidate's excellent academic record and proposed project at Sciences Po. 1. This grant is applicable to the people residing at Gulf countries. 2. Applicants must be first-time degree seeking at France. 3. Applicants must have. i. Submitted a full application to Sciences Po (including all supporting documents and references). ii. Applied to any of the 7 graduate schools of Sciences Po, if any of the two-year Masters program

Level of Study: Postgraduate

Type: Scholarship

Value: Multiple scholarships of up to $€ 10,000$ per year will be awarded for the 2 years of study

Frequency: Annual

Country of Study: Any country

Application Procedure: Detailed information on this grant is available on the below file. www.sciencespo.fr/kuwaitprogram/wp-content/uploads/2018/10/Call-for-applications2019-Kuwait-Excellence-Scholarship-for-Students-from-theArab-World.pdf

Closing Date: 16 February

Additional Information: The Kuwait Program at Sciences Po (KSP) is a partnership between the Kuwait Foundation for the Advancement of Sciences (KFAS) and Sciences Po, based at the Paris School of International Affairs www.sciencespo. fr/kuwait-program/student-activities/scholarship/

\section{For further information contact:}

27, rue Saint Guillaume, F-75337 Paris Cedex 07, France.

Tel: (33) 145495050

Email: program.kuwait@sciencespo.fr

\section{Parkinson's United Kingdom}

215 Vauxhall Bridge Road, London, SW1V 1EJ, United Kingdom.

Tel:

Email: researchapplications@parkinsons.org.uk

Website: www.parkinsons.org.uk

Contact: Ms Bunia Gorelick, Research Grants Manager

Founded in 1969, Parkinson's UK is a charity that focuses on information and support, research, education and training and campaigning.

\section{Clinician Scientist Fellowship}

Purpose: To support MDs and other health professionals studying for a $\mathrm{PhD}$.

Level of Study: Doctorate

Value: Up to $£ 250,000$

Length of Study: 3 years

Frequency: Annual

Country of Study: United Kingdom

Application Procedure: Please see website

Additional Information: mrc.ukri.org/skills-careers/fellow ships/clinical-fellowships/clinician-scientist-fellowship-csf/

For further information contact:

Email: cindy@cmscfoundation.org

\section{Paul \& Daisy Soros Fellowships for New Americans}

400 West 59th Street, 4th floor, New York, NY 10019, United States of America.

Tel: $\quad$ (1) 2125476926

Email: pdsoros_fellows@sorosny.org

Website: www.pdsoros.org

\section{The Paul \& Daisy Soros Fellowship for New Americans}

Purpose: To provide opportunities for continuing generations of able and accomplished New Americans to achieve leadership in their chosen fields

Eligibility: Open to New Americans: resident aliens (Green Card Holders) naturalized United States citizens and/or children of 2 naturalized parents

Level of Study: Postdoctorate

Type: Fellowship

Value: US $\$ 25,000$ up to US\$20,000 in tuition support for each year

Length of Study: 2 years

Study Establishment: Any accredited graduate University in the United States

Country of Study: United States of America

Application Procedure: Apply online

No. of awards offered: 77

Closing Date: 12 November

Funding: Private

Contributor: Paul and Daisy Soros 
No. of awards given last year: 30

No. of applicants last year: 77

Additional Information: pdsoros-fellowships.fluidreview. com/prog/2020_application/

For further information contact:

Email: pdsoros@pdsoros.org

\section{Paul Lowin Prizes}

Perpetual Trustees Australia Limited, 39 Hunter Street, Sydney, NSW 2000, Australia.

Tel: $\quad$ (61) 292293951

Email: lowinprizes@perpetual.com.au

Website: www.paullowin.perpetual.com.au

Contact: Charitable Planning Services Administration

The Paul Lowin Prizes are administered by the Perpetual Trustees Australia Limited, which is a public trustee company operating in all mainland states of Australia. It is the sole or co-trustee of 360 charitable trusts and foundations with a value of approximately AU $\$ 580$ million. Income generated from investment of this capital is distributed annually to charitable organisations to fulfil the intent of the trusts under management.

\section{Paul Lowin Prizes - Song Cycle Prize}

Purpose: To recognise original composition. For the purposes of the competition, a song cycle is music suitable for chamber performance

Eligibility: The composer must be at least 18 years of age and an Australian citizen or a resident of Australia for not less than three years prior to the closing date

Level of Study: Unrestricted

Type: Prize

Value: AU $\$ 15,000$

Frequency: Every 2 years

Country of Study: Any country

Application Procedure: Applicants must refer to the website for details

No. of awards offered: 10

Closing Date: 30 June

Funding: Private

No. of awards given last year: 1

No. of applicants last year: 10

Additional Information: Works should use no more than one-eight independent vocal lines, which may be accompanied by up to 10 instrumental players. The text of the work may have a unifying theme, and the composer and the author of the text may or may not be different people, but the author of the text is not eligible for the prize. The work may be no less than 15 minutes and no more than 60 in duration taitmemorialtrust. org/tag/paul-lowin-song-cycle-prize/

\section{For further information contact:}

Australian Music Centre, Level 4, The Arts Exchange, 18 Hickson Road, Dawes Point, NSW 2000, Australia.

Email: info@australianmusiccentre.com.au

\section{Peninsula School of Medicine and Dentistry}

The John Bull Building, Tamar Science Park, Research Way, Plymouth, PL6 8BU, United Kingdom.

Tel: $\quad$ (44) 1752437474

Email: info@psmd.ac.uk

Website: www.pcmd.ac.uk

Peninsula Medical School and Peninsula Dental School have come together in The Peninsula College of Medicine and Dentistry, a partnership with the University of Exeter

\section{Peninsula College of Medicine and Dentistry PhD Studentships}

Purpose: To attract $\mathrm{PhD}$ candidates of outstanding ability to join their exciting and rapidly expanding programme of internationally rated research

Eligibility: Open to the suitably qualified graduates

Level of Study: Doctorate

Type: Studentship

Value: $£ 13,290$ (Research Council Rate)

Frequency: Dependent on funds available

Study Establishment: Peninsula College of Medicine \& Dentistry

Country of Study: United Kingdom

Application Procedure: Check website for the details

Closing Date: 8 November

Contributor: Various sources

Additional Information: scholarship-positions.com/student ship-peninsula-college-of-medicine-dentistry/2007/10/31/ 


\section{Penn State, College of \\ Communications}

\section{Call for Proposals: Narratives in Public Communications}

Purpose: Organizational members use narratives to make sense of the organizational culture. The increased use of narratives in public communication calls for additional research that we hope will help shed new light on their applications and influences in these areas

Eligibility: This call therefore seeks grant proposals that will examine the uses and implications of stories and storytelling in public communications

Level of Study: Graduate

Type: Grant

Frequency: Annual

Country of Study: Any country

Application Procedure: Check the application procedure at the link below. The proposal requires the below information to process further. 1. Narrative (up to 5 pages). 2. Abstract (1 page). 3. Coversheet (1 page). 4. Budget (1 page). Curriculum Vitae or Professional Resume. bellisario.psu.edu/pagecenter/grants/legacy-scholar-grants/guidelines-for-grantapplications

Closing Date: 15 January

Funding: Private

Additional Information: bellisario.psu.edu/page-center/ grants/legacy-scholar-grants/2019-call-for-grant-proposals

\section{For further information contact:}

4 Carnegie Building, University Park, PA 16802, United States America.

Email: cuc15@psu.edu

\section{Perkins School of Theology}

Southern Methodist University, PO Box 750133, Dallas, TX 75275-0133, United States of America.

Tel: $\quad$ (1) 2147688436

Email: theology@smu.edu

Website: www.smu.edu/perkins

Perkins School of Theology is one of the 13 seminaries of The United Methodist Church (and one of the only 5 university- related United Methodist theological schools), located in the heart of Dallas, Texas, with extension programmes in Houston/Galveston and San Antonio.

\section{Diaconia Graduate Fellowships}

Purpose: To supplement the financial resources of United Methodist students

Eligibility: Open to consecrated diaconal ministers or ordained deacons and full-time Doctoral students

Level of Study: Doctorate

Type: Fellowships

Value: US $\$ 10,000$

Frequency: Annual

Application Procedure: Request for application forms can be sent to theology@smu.edu

Closing Date: 31 December

Contributor: Section of Deacons and Diaconal Ministries, General Board of Higher Education and Ministry, The United Methodist Church

Additional Information: www.collegescholarships.com/ scholarships/detail/110106

\section{For further information contact:}

Diaconia Graduate Fellowships Section of Deacons and Diaconal Ministries, PO Box 340007, Nashville, TN 37203-0007, United States of America.

Tel: $\quad$ (1) 6153407375

Fax: (1) 5106491730

Email: finaid@gtu.edu

\section{Petro Jacyk Central \& East European Resource Centre (PJRC)}

University of Toronto, 27 King's College Circle, Toronto, ON M5S, Canada University of Toronto.

Email:_jacyk.program@utoronto.ca

Contact: Petro Jacyk Program for the Study of Ukraine

The PJRC supports the activities of the centre for European, Russian and Eurasian studies, the Department of Slavic Languages and Literatures and the 5 research chairs connected with Estonian, Finnish, Hungarian, Polish History and Ukranian studies. 


\section{Petro Jacyk Program}

Purpose: The objective of the Post-Doctoral Fellowship is to support annually one of the most promising junior scholars studying contemporary Ukraine and thereby to advance academic understanding of Ukrainian politics, culture, and society

Eligibility: The Petro Jacyk Post-Doctoral Fellowship is available to junior scholars in the social sciences and humanities with a research and teaching focus on contemporary Ukraine. The fellowship is open to recently awarded $\mathrm{PhDs}$ (persons holding doctorates for no more than three years at the time of application)

Level of Study: Postdoctorate

Type: Fellowship

Value: $\mathrm{C} \$ 40,000$, which includes payment for teaching a semester-long course, and separately an allowance of up to $\mathrm{C} \$ 2,500$ for research and travel expenses

Length of Study: 1 year

Study Establishment: University of Toronto

Country of Study: Canada

Application Procedure: Please send applications by email to: the Foundation at pjef@bellnet.ca and the Petro Jacyk Program for the Study of Ukraine at the University of Toronto at jacyk.program@utoronto.ca simultaneously

Closing Date: 1 February

Contributor: Petro Jacyk Education Foundation

Additional Information: For more information on the postdoctoral fellowship, please visit our website. sites.utoronto. ca/jacyk/postdoctoral www.science-community.org/en/node/ 161353

\section{Pfizer}

Pfizer MAP Program, MedPoint Communications, 1603 Orrington Ave, Suite 1900, Evanston, IL 60201, United States of America.

Tel: (1) 8772546953

Email:_MAPinfo@clinicalconnexion.com

Website: www.pfizermap.com

Contact: MAP Program Coordinator

As a reflection of commitment to the advancement of healthcare, Pfizer Inc. supports medical innovation in a wide range of discipline through its Medical and Academic Partnership (MAP) grants and awards. The Fellowships and Scholar Grants, which offer career-building opportunities for academic researchers in basic, outcomes, and patientoriented research, are key among these efforts. In addition,
Pfizer Visiting Professorships continue to be a resource for in-depth, clinically focused exchange between medical scholars, host organizations and outside scholar-scientists.

\section{Acromegaly/Growth Hormone Excess Research}

Purpose: Pfizer Global Medical Grants (GMG) supports the global healthcare community's independent initiatives (e.g., research, quality improvement or education) to improve patient outcomes in areas of unmet medical need that are aligned with Pfizer's medical and/or scientific strategies. Pfizer's GMG competitive grant program involves a publicly posted Request for Proposal (RFP) that provides detail regarding a specific area of interest, sets timelines for review and approval, and uses an external review panel (ERP) to make final grant decisions. Organizations are invited to submit an application addressing the specific gaps in research, practice or care as outlined in the specific RFP. For all Investigator Sponsored Research (ISRs) and general research grants, the grant requester (and ultimately the grantee) is responsible for the design, implementation, sponsorship, and conduct of the independent initiative supported by the grant, including compliance with any regulatory requirements. Pfizer must not be involved in any aspect of study protocol or project development, nor the conduct or monitoring of the research program.

Eligibility: The institution and principal investigator (PI) must be based in one of the eligible countries noted above. 1. Only organizations are eligible to receive grants, not individuals or medical practice groups. 2. The applicant (PI) must have a medical or postdoctoral degree (MD, $\mathrm{PhD}$, or equivalent), an advanced nursing degree (BSN with a MS/PhD), or a degree in Pharmacy, Physiotherapy, or Social Work. 3. Applicant must be affiliated with a host institution 4. Both early career and experienced investigators are encouraged to apply and consideration will be given to all proposals meeting the selection criteria

Level of Study: Postgraduate

Type: Grant

Value: Individual projects requesting up to US\$100,000 will be considered. Pfizer anticipates awarding up to 1 grant 1 . The amount of the grant Pfizer will be prepared to fund for any project will depend upon the external review panel's evaluation of the proposal and costs involved, and will be stated clearly in the approval notification

Frequency: Annual

Country of Study: United States of America

Application Procedure: 1. Please go to www.cybergrants. com/pfizer/Research and sign in. First-time users should click "Create your password". Requirements for submission: 2. Select the following Competitive Grant Program Name: 
2020 RD LAcromegaly/Growth Hormone Excess Research US 3. Complete all required sections of the online application. See Appendix A for additional details 4. If you encounter any technical difficulties with the website, please click the "Technical Questions" link at the bottom of the page

No. of awards offered: 1

Closing Date: 28 May

Additional Information: www.pfizer.com/purpose/ independent-grants/competitive-grants

\section{For further information contact:}

Email: amanda.j.stein@pfizer.com

\section{Breast Cancer Competitive Research Grant Program}

Purpose: Pfizer Global Medical Grants (GMG) supports the global healthcare community's independent initiatives (e.g., research, quality improvement or education) to improve patient outcomes in areas of unmet medical need that are aligned with Pfizer's medical and/or scientific strategies. Pfizer's GMG competitive grant program involves a publicly posted Request for Proposal (RFP) that provides detail regarding a specific area of interest, sets timelines for review and approval, and uses an external review panel (ERP) to make final grant decisions. Organizations are invited to submit an application addressing the specific gaps in research, practice or care as outlined in the specific RFP. For all Investigator Sponsored Research (ISRs), general research and medical education grants, the grant requester (and ultimately the grantee) is responsible for the design, implementation, sponsorship, and conduct of the independent initiative supported by the grant, including compliance with any regulatory requirements. Pfizer must not be involved in any aspect of study protocol or project development, nor the conduct or monitoring of the project.

Eligibility: The principal investigator (PI) and institution must be based in one of the eligible regions noted above. 1. The applicant (PI) must have a medical or postdoctoral degree (MD, $\mathrm{PhD}$, or equivalent). 2. Applicant must be affiliated with a host institution. 3. Both early career and experienced investigators are encouraged to apply and consideration will be given to all proposals meeting the selection criteria. 4 . If the project involves multiple departments within an institution and/or between different institutions/ organizations/associations, all institutions must have a relevant role and the requesting organization must have a key role in the project.

Level of Study: Postgraduate

Type: Grant
Value: A total of US\$3 million is allocated to this grants program. 1. Applications will be reviewed by an independent review panel. Up to 15 projects will be selected for funding. 2. The amount of the grant Pfizer will be prepared to fund for any project will depend upon the external review panel's evaluation of the proposal and costs involved, and will be stated clearly in the approval notification.

Frequency: Annual

Country of Study: United States of America

Application Procedure: Please go to www.cybergrants.com/ pfizer/Research and sign in. Firsttime users should click "REGISTER NOW". Requirements for submission: 1. Select the following Competitive Grant Program Name: 2020 Breast Cancer Competitive Research for AfME, Asia, LatAm 2. Complete all required sections of the online application. See Appendix A for additional details. All applications must be in English. 3. If you encounter any technical difficulties with the website, please click the "Technical Questions" link at the bottom of the page

\section{Closing Date: 7 April}

Additional Information: www.pfizer.com/purpose/ independent-grants/competitive-grants

\section{For further information contact:}

\section{Email: Jessica.Romano@pfizer.com}

\section{Growth Hormone Research}

Purpose: Pfizer Global Medical Grants (GMG) supports the global healthcare community's independent initiatives (e.g., research, quality improvement or education) to improve patient outcomes in areas of unmet medical need that are aligned with Pfizer's medical and/or scientific strategies. Pfizer's GMG competitive grant program involves a publicly posted Request for Proposal (RFP) that provides detail regarding a specific area of interest, sets timelines for review and approval, and uses an external review panel (ERP) to make final grant decisions. Organizations are invited to submit an application addressing the specific gaps in research, practice or care as outlined in the specific RFP. For all Investigator Sponsored Research (ISRs) and general research grants, the grant requester (and ultimately the grantee) is responsible for the design, implementation, sponsorship, and conduct of the independent initiative supported by the grant, including compliance with any regulatory requirements. Pfizer must not be involved in any aspect of study protocol or project development, nor the conduct or monitoring of the research program.

Eligibility: The institution and principal investigator (PI) must be based in one of the eligible countries noted above. 1. Only organizations are eligible to receive grants, 
not individuals or medical practice groups. 2. The applicant (PI) must have a medical or postdoctoral degree (MD, $\mathrm{PhD}$, or equivalent), an advanced nursing degree (BSN with a MS/PhD), or a degree in Pharmacy, Physiotherapy, or Social Work. 3. Applicant must be affiliated with a host institution 4. Both early career and experienced investigators are encouraged to apply and consideration will be given to all proposals meeting the selection criteria

Level of Study: Postgraduate

Type: Grant

Value: Individual projects requesting up to US\$100,000 will be considered. Pfizer anticipates awarding up to 1 grant 1 . The amount of the grant Pfizer will be prepared to fund for any project will depend upon the external review panel's evaluation of the proposal and costs involved, and will be stated clearly in the approval notification

Frequency: Annual

Country of Study: United States of America

Application Procedure: Please go to www.cybergrants.com/ pfizer/Research and sign in. First-time users should click "Create your password". Requirements for submission: 1. Select the following Competitive Grant Program Name: 2020 RD LPediatric Growth Hormone Deficiency Research US 2. Complete all required sections of the online application. See Appendix A for additional details 3. If you encounter any technical difficulties with the website, please click the "Technical Questions" link at the bottom of the page

No. of awards offered: 1

Closing Date: 28 May

Additional Information: www.pfizer.com/purpose/ independent-grants/competitive-grants

\section{For further information contact:}

Email:amanda.j.stein@pfizer.com

\section{Global Hemophilia ASPIRE}

Purpose: Projects that will be considered for Pfizer support will focus on the following areas in Gene Therapy for Hemophilia A or B: Basic Science of Gene Therapy for Hemophilia; Basic Science of TFPI \& Anti-TFPI Monoclonal Antibodies; ross talk among regulators (e.g., Protein $\mathrm{S}$ being a co-factor for both Protein $\mathrm{C}$ and TFPI); AND Patients with MILD Hemophilia A or B.

Eligibility: The applicant (PI) must have a medical or postdoctoral degree (MD, $\mathrm{PhD}$, or equivalent), an advanced nursing degree (BSN with a MS/PhD), or a degree in Pharmacy, Physiotherapy, or Social Work.

Level of Study: Postdoctoral

Type: Grants

Value: US\$250,000
Length of Study: 1 to 2 year

Frequency: Annual

Closing Date: 31 August

Additional Information: pfe-pfizercom-prod.s3.amazonaws. com/Competitive $\% 20$ Grant $\% 20$ Program $\% 20$ RFP_ Research Hemophilia_GLOBAL.pdf

\section{For further information contact:}

Email: amanda.j.stein@pfizer.com

\section{Pfizer Scholar}

Purpose: To support cancer development in epidemiology Eligibility: Open to individuals who are pursuing research in epidemiology relevant to human health

Level of Study: Postgraduate

Type: Grant

Value: US\$130,000

Length of Study: 2 years

Frequency: Annual

Country of Study: Any country

Application Procedure: A completed application form must be submitted

Closing Date: 6 January

Funding: Commercial

Additional Information: www.collegescholarships.org/ scholarships/companies/pfizer.htm

\section{For further information contact:}

Email: mzebrowski@metrohealth.org

\section{Pfizer Scholars Grants in Clinical Epidemiology}

Purpose: To support the career development of junior faculty Eligibility: Citizens or permanent residents of the United States of America who have a doctoral degree, relevant research experience and postdoctoral clinical training appropriate for the proposed research are encouraged to apply. The applicant should hold a junior faculty position (with 2 years of appointment as an instructor, an assistant professor or an equivalent junior faculty rank) at an accredited academic medical institution

Level of Study: Professional development

Type: Grant

Value: US\$195,000

Length of Study: 3 years

Frequency: Annual

Country of Study: United States of America 
Application Procedure: Applicants must visit the website for full details on the application process

Closing Date: 5 January

Funding: Corporation

Contributor: Pfizer Inc

\section{For further information contact:}

Email: mzebrowski@metrohealth.org

\section{Pfizer Scholars Grants in Clinical Psychiatry}

Purpose: To support the development of junior faculty Eligibility: Citizens or permanent residents of the United States of America who are junior faculty with a doctoral degree (with 2 years of appointment as an instructor, an assistant professor or an equivalent junior faculty rank) at an accredited academic medical institution are encouraged to apply

Level of Study: Professional development

Type: Grant

Value: US\$130,000

Length of Study: 2 years

Frequency: Annual

Country of Study: United States of America

Application Procedure: Applicants must visit the website for full details

Closing Date: 5 January

Funding: Corporation

Contributor: Pfizer Inc

\section{For further information contact:}

Email: mzebrowski@metrohealth.org

\section{Pfizer Scholars Grants in Clinical Rheumatology}

Purpose: To support the career development of junior faculty Eligibility: Citizens or permanent residents of the United States of America who have a doctoral degree, relevant research experience and postdoctoral clinical training appropriate for the proposed research are encouraged to apply. The applicant should hold a junior faculty position (with 2 years of appointment as an instructor, an assistant professor or an equivalent junior faculty rank) at an accredited academic medical institution

Level of Study: Professional development

Type: Grant

Value: Up to US $\$ 130,000$

Length of Study: 2 years

Frequency: Annual

Country of Study: United States of America
Application Procedure: Applicants must visit the website for details on the application process

Closing Date: 24 February

Funding: Corporation

Contributor: Pfizer Inc

Additional Information: researchfunding.duke.edu/2020rheumatology-fellowship-competitive-grant-program

\section{For further information contact:}

Email: Amanda.solis@pfizer.com

\section{Pfizer Scholars Grants in Pain Medicine}

Purpose: To support the career development of junior faculty Eligibility: Citizens or permanent residents of the United States of America who have a doctoral degree, relevant research experience are encouraged to apply. The applicant should hold a junior faculty position (with 2 years of appointment as an instructor, an assistant professor or an equivalent junior faculty rank) at an accredited academic medical institution

Level of Study: Professional development

Type: Grant

Value: US\$130,000

Length of Study: 2 years

Frequency: Annual

Country of Study: United States of America

Application Procedure: Applicants must visit the website for details on the application process

Closing Date: 5 January

Funding: Corporation

Contributor: Pfizer Inc

For further information contact:

Email: mzebrowski@metrohealth.org

\section{Pfizer Visiting Professorships Program}

Purpose: To create opportunities for selected institutions to invite a distinguished expert for three days of teaching

Eligibility: Open to accredited medical schools and/or affiliated teaching hospitals

Level of Study: Postgraduate

Type: Grant

Value: US\$7,500 each

Frequency: Annual

Country of Study: Any country

Application Procedure: Applications available online

Closing Date: 12 February 
Additional Information: researchfunding.duke.edu/pfizervisiting-professorship-program

\section{For further information contact:}

Email: mzebrowski@metrohealth.org

\section{Transthyretin Amyloidosis (ATTR) Competitive Grant Program/ ASPIRE}

Subjects: Transthyretin Amyloidosis (ATTR) including cardiomyopathy, peripheral neuropathy, and mixed phenotypes

Purpose: The intent of this Request for Proposal (RFP) is to improve the care of patients with ATTR by improving our understanding of disease epidemiology, pathophysiology, early diagnosis, prognosis, and emerging treatment paradigms.

Eligibility: Only organizations are eligible to receive grants, not individuals or medical practice groups. The principal investigator (PI) and institution must be based in one of the eligible countries noted above. The applicant (PI) must have a medical or postdoctoral degree (MD, $\mathrm{PhD}$, or equivalent), an advanced nursing degree (BSN with a $\mathrm{MS} / \mathrm{PhD}$ ), or a degree in Pharmacy, Physiotherapy, or Social Work. Applicant must be affiliated with a host institution. Both early career and experienced investigators are encouraged to apply and consideration will be given to all proposals meeting the selection criteria

Type: Grant

Value: Up to US $\$ 75,000$

Country of Study: United States of America

Application Procedure: Go to www.cybergrants.com/pfizer/ Research and sign in. First-time users should click "REGISTER NOW"

No. of awards offered: $U p$ to four

Closing Date: 17 May

\section{Phi Beta Kappa Society}

1606 New Hampshire Avenue NW, Washington, DC 20009, United States of America.

Tel: (1) 2022653808

Email: info@pbk.org

Website: www.pbk.org

The Phi Beta Kappa Society has pursued its mission of fostering and recognizing excellence in the liberal arts and sciences since 1776 .

\section{The Mary Isabel Sibley Fellowship}

Purpose: To recognize female scholars who have demonstrated their ability to carry out original research

Eligibility: Candidates must be unmarried women 25-35 years of age who have demonstrated their ability to carry on original research. They must hold a doctorate or have fulfilled all the requirements for a doctorate except the dissertation, and they must be planning to devote full-time work to research during the fellowship year. The award is not restricted to members of Phi Beta Kappa or to United States citizens

Level of Study: Doctorate, Postdoctorate, Postgraduate

Type: Fellowship

Value: US\$20,000

Length of Study: 1 year, non-renewable

Frequency: Annual

Country of Study: Any country

Application Procedure: Applicants must complete an application form, available from the website, and submit this with transcripts and references

No. of awards offered: 50

Closing Date: 15 January

Funding: Private

No. of awards given last year: 1

No. of applicants last year: 50

Additional Information: researchfunding.duke.edu/maryisabel-sibley-fellowship-women-scholars-french-or-greek

\section{For further information contact:}

Email:awards@pbk.org

\section{PhRMA Foundation}

\section{Postdoctoral Fellowship in Health Outcomes Research}

Subjects: Health outcomes research

Purpose: This award supports individuals engaged in a research training program that will extend their credentials in health outcomes research.

Eligibility: Applicants (U.S. and non-U.S. citizens) attending schools of medicine, pharmacy, public health, nursing, and dentistry are eligible for this award. Applicants must 1) hold a $\mathrm{PhD}$ degree or appropriate terminal research doctorate in a field of study logically or functionally related to the proposed postdoctoral activities or 2) expect to receive the $\mathrm{PhD}$ before activating the award.

Type: Fellowship

Value: US $\$ 55,000$ per year for stipend only

Length of Study: Two year

Country of Study: United States of America 


\section{Closing Date: 3 February}

Additional Information: www.phrmafoundation.org/2018awards/post-doctoral-fellowships/health-outcomes/

\section{Postdoctoral Fellowship in Translational Medicine}

Subjects: Translational Medicine

Purpose: This award supports individuals engaged in multidisciplinary/collaborative research training programs that will extend their credentials in Translational Medicine.

Eligibility: Eligible candidates (U.S. and non-U.S. citizens) will have doctoral degrees, e.g., $\mathrm{PhD}$, D.Sc, D.Eng, MD, and seek to further develop and refine their skills and understanding of Translational Medicine through postdoctoral training. Applicants must write and submit a research plan and provide the mentor's research record, as well as a description of how the mentoring experience will enhance the applicant's career development in Translational Medicine. A key component of Translational Medicine involves collaborative programs that span non-clinical and clinical domains, potentially involving multiple laboratories, advisers, and institutions.

Type: Fellowship

Value: US\$60,000 per year

Length of Study: Up to two years

Frequency: Varies

Country of Study: Any country

Closing Date: 3 February

Additional Information: www.phrmafoundation.org/2018awards/post-doctoral-fellowships/translational-medicine/

\section{Pierre Elliott Trudeau Foundation}

Tel: (1) 5149380001 , extension 230

Email: competition@trudeaufoundation.ca

Contact: Josée St-Martin, Program Director, Doctoral Scholarships

\section{Pierre Elliott Trudeau Foundation Doctoral Scholarships}

Eligibility: Open to Canadian citizen, permanent resident of Canada, foreign citizens; full-time first or second year students enrolled (or in the process of enrolling) in a doctoral programe in the humanities and social sciences

Type: Scholarship

Value: $C \$ 40,000$ per year; $C \$ 20,000$ per year for research and travel allowance

Length of Study: 3 years

Country of Study: Canada

Closing Date: November
Contributor: Pierre Elliott Trudeau Foundation

No. of awards given last year: 15

Additional Information: For more details, please visit the Contact Centre: support@cihr-irsc.gc.ca www.trudeauf oundation.ca/en/programs/scholarships/become-scholar

\section{For further information contact:}

Email: scholarships@trudeaufoundation.ca

\section{Pine Tree State 4-H Foundation}

\section{Azure Dillon 4-H Memorial Scholarship}

Eligibility: The qualified candidate must be: 1 . a current member of 4-H (enrolled by 31 December) who is currently active in 4-H activities and. 2. a graduating senior or an individual who has graduated from high school, but has delayed going to college for no more than one year. Candidates are only eligible to apply in the spring prior to entering college

Level of Study: Postgraduate

Type: Scholarship

Value: US $\$ 1,000$

Frequency: Annual

Country of Study: Any country

Application Procedure: Scholarships are awarded based on a combination of demonstrated academic and 4-H excellence. Recipients will be requested to attend the foundation's annual meeting to receive their scholarship in person

No. of awards offered: 1

Closing Date: 2 March

Funding: Private

Additional Information: www.unigo.com/scholarships/bystate/maine-scholarships/azure-dillon-4-h-memorial-scholar ship/1470

\section{For further information contact:}

5741 Libby Hall, Room 103, Orono, ME 04469-5741, United States of America.

Tel: (1) 2073535550

\section{Plymouth University}

Drake Circus, Plymouth, Devon PL4 8AA, United Kingdom.

Tel:

$$
\text { (44) } 1752600600
$$

Email:_prospectus@plymouth.ac.uk

Website: www.plymouth.ac.uk 


\section{International Postgraduate Gaza Scholarships}

Purpose: These scholarships will be awarded on a competitive basis to prospective masters students

Eligibility: 1. Be a citizen of Gaza. 2. Be self-funding and classified as overseas for tuition fee purposes. 3. Hold a conditional or unconditional offer from the University of Sheffield before Friday 25 May 2020 to study a full-time postgraduate taught Masters' course starting in September 2020.

Type: Scholarship

Value: Each scholarship will be for a fee discount of $£ 5,000$ on a masters programme at Plymouth University

Country of Study: United Kingdom

Application Procedure: Please send completed application form as an attachment to internationalscholarships@plym outh.ac.uk along with a copy of your offer letter; a copy of final transcript/marks sheet from undergraduate degree (if final transcript is not available at the time of application please send the most recent or provisional results); a reference letter, from a suitable source, supporting this scholarship application (please do not supply the same reference as that submitted with the postgraduate application). www.plym outh.ac.uk/uploads/production/document/path/5/5758/Gaza Scholarship2016.docx

Closing Date: 1 June

Additional Information: Please check at www1.plymouth. ac.uk/money/support13-14/Pages/international.aspx\#PIS www.sheffield.ac.uk/international/fees-and-funding/scholar ships/postgraduate/gaza

\section{For further information contact:}

Tel: $\quad$ (44) 1142221319

Email: financialhelp@sheffield.ac.uk

\section{International Student Merit Scholarship}

Eligibility: Applicants must have received a conditional offer of a place for a postgraduate taught programme commencing in September and be holding the equivalent of a United Kingdom university 1 class Bachelors degree in a relevant subject Type: Scholarship

Value: $£ 2,500$

Country of Study: United Kingdom

Application Procedure: Applicants can apply via email. For detailed information, please visit website

Closing Date: 4 May

Additional Information: Please check at website www.shef field.ac.uk/international/fees-and-funding/scholarships/under graduate/international-undergraduate-merit-scholarship

\section{For further information contact:}

The University of Sheffield, Western Bank, Sheffield, S10 2TN, England.

Tel: (44) 1142222000

\section{International Student PGT Scholarship}

Purpose: Scholarships are available for international students who wish to study postgraduate taught degree courses

Eligibility: Applicants should hold a conditional offer of a place on a postgraduate taught degree programme at Plymouth University. The University will automatically consider applicants with relevant Bachelor degree grades as stipulated in the list. Please note this eligibility criteria list is not exhaustive and graduates from all non-EU countries will be considered for these scholarships. The Bachelor's degree must be the equivalent of a United Kingdom Honours degree, as specified by United Kingdom NARIC. For detailed information, please visit Level of Study: Postgraduate

Type: Scholarship

Value: $£ 1,500$

Country of Study: United Kingdom

Application Procedure: If the student has applied for a postgraduate taught degree programme, they will automatically be considered for this scholarship if their final transcript or marks sheet was submitted with their application.

Additional Information: studyabroad.shiksha.com/scholar ships/school-of-management-pgt-scholarship-ma-internationaldevelopment-management

\section{For further information contact:}

Tel: $\quad$ (44) 1274236637

Email: scholarships@bradford.ac.uk

\section{Poets Essayists Novelists American Center}

588 Broadway, Suite 303, New York, NY 10012, United States of America.

Tel:

Email: pen@pen.org

Website: www.pen.org

Contact: Paul W Morris, Awards Director

PEN American Center is a fellowship of writers dedicated to advance literature, depend free expression and foster 
international fellowship. The American Center is the largest of 145 international PEN centers worldwide.

\section{The PEN Translation Fund Grants}

Purpose: The fund seeks to encourage translators to undertake projects they might not otherwise have had the means to attempt

Eligibility: Book-length works that have not previously appeared in English in print or have appeared only in an outdated or flawed translation

Level of Study: Unrestricted

Type: Grant

Value: US $\$ 2,000-4,000$

Frequency: Annual

Country of Study: Any country

Application Procedure: All applications must include the cover sheet and items outlined at www.pen.org/awards

No. of awards offered: 140

Closing Date: 1 June

Funding: Private

No. of awards given last year: 11

No. of applicants last year: 140

Additional Information: Anthologies with multiple translators, works of literary criticism and scholarly or technical texts do not qualify. Translators awarded grants by the fund are ineligible to reapply for 3 years after the year they receive a grant. Please check the website for more details pen.org/ pen-heim-grants/

\section{For further information contact:}

PEN Literary Awards, PEN Translation Fund, PEN American Center, 588 Broadway 303, New York, NY 10012, United States of America.

Email: awards@pen.org

\section{Polycystic Kidney Disease Foundation}

9221 Ward Parkway, Suite 400, Kansas City, MO 64114 3367, United States of America.

Tel: $\quad$ (1) 8169312600

Email: pkdcure@pkdcure.org

Website: www.pkdcure.org

Contact: Administrative Assistant

The PKD Foundation is the only organization worldwide solely devoted to promoting research into finding a cure for polycystic kidney disease (PKD) and to improving the care and treatment of those affected by it.

\section{Polycystic Kidney Disease Foundation Grant-In-Aid}

Purpose: To encourage researchers to conduct research on PKD

Eligibility: Research Grants are open to basic and clinical principal investigators with quality projects relevant to finding a treatment and/or cure for PKD. Research Fellowships are open to promising postdoctoral researchers who have the potential to become productive, independent investigators in PKD research

Level of Study: Doctorate, Graduate, Postdoctorate, Predoctorate, Research

Type: Research grant or fellowship

Value: Research Grants: US $\$ 65,000$ per year; fellowships: US $\$ 50,000$ per year

Length of Study: Two years, renewable for a third year, pending scientific review and availability of funding

Frequency: Annual

Country of Study: Any country

Application Procedure: Application must not exceed a total of 18 pages; otherwise, it will be returned without review. Application guidelines will be available on the PKD foundation website after 1 April. Late applications will not be accepted. Please visit the website for complete application information

No. of awards offered: 71

Closing Date: 1 August

Funding: Private, Corporation, Foundation, Trusts, Individuals

Contributor: Individuals

No. of awards given last year: 46

No. of applicants last year: 71

For further information contact:

Email: research@pkdcure.org

\section{Population Council}

Policy Research Division, One Dag Hammarskjold Plaza, New York, NY 10017, United States of America.

Tel: $\quad$ (1) 2123390500

Email:_ssfellowship@popcouncil.org

Website: www.popcouncil.org

Contact: Fellowship Co-ordinator 
The Population Council is an international non-profit, non-governmental institution that seeks to improve the well being and reproductive health of current and future generations around the world and to help achieve a humane, equitable and sustainable balance between people and resources. The Council conducts biomedical, social science and public health research and helps build research capacities in developing countries.

\section{Health and Population Innovation Fellowship Program}

Purpose: To support mid-career individuals who have innovative ideas and the capacity to help shape public debate in the field of population, rights and reproductive health

Level of Study: Postdoctorate, Professional development Type: Fellowship

Length of Study: 1 year

Frequency: Annual

Study Establishment: The Population Council, New Delhi

Country of Study: India

Application Procedure: Request application form

Closing Date: 15 September

Funding: Foundation

Contributor: John D. and Catherine T. MacArthur

Foundation

No. of awards given last year: 12

Additional Information: nursing.duke.edu/centersinstitutes/center-nursing-research/postdoctoral-fellowshiphealth-innovation

\section{For further information contact:}

Zone 5A, Ground Floor India Habitat Centre, Lodi Road, New Delhi, Delhi 110003, India.

Tel: $\quad$ (91) 1124642901

Fax: (91) 1124642903

Email: fellowships@pcindia.org

\section{Transmission of Immunodeficiency Viruses: Postdoctoral Research Position}

Additional Information: www.niaid.nih.gov/about/ postdoctoral-research-training

\section{For further information contact:}

Center for Biomedical Research, Population Council, 1230 York Avenue, New York, NY 10065, United States of America.

$\begin{array}{ll}\text { Tel: } & \text { (1) } 2123277794 \\ \text { Fax: } & \text { (1) } 2123277764\end{array}$

Email: mpope@popcouncil.org

\section{Prehistoric Society}

Institute of Archaeology, University College London, 31-34 Gordon Square, London, WC1H OPY, United Kingdom.

Email:_prehistoric@ucl.ac.uk

Website: www.prehistoricsociety.org

Contact: Ms Tessa Machling, Administrative Assistant

The Prehistoric Society is open to professionals and amateurs alike and has over 2,000 members worldwide. Its main activities are lectures, study tours and conferences and it publishes an annual journal (PPS) and a newsletter (PAST), which is published 3 times a year.

\section{Prehistoric Society Conference Fund}

Purpose: It's aim is to further the development of prehistory as an international discipline. To offer funding to those who might not otherwise be able to travel to an international conference

Eligibility: There are no eligibility restrictions

Level of Study: Unrestricted

Type: Scholarship

Value: $£ 200-300$

Frequency: Annual

Application Procedure: Applications from both members and non-members will be considered. Applications may also be made by conference organisers, on behalf of attending scholars. Please check website for application: www.pre historicsociety.org/grants/conference_fund/

Closing Date: 31 January

Funding: Private

Additional Information: www.prehistoricsociety.org/grants/ conference_fund/

\section{For further information contact:}

Administrative Assistant, Prehistoric Society, Institute of Archaeology, 31-34 Gordon Square, London, WC1H OPY, UK.

\section{Research Fund}

Purpose: The Research Grant aims to offer small 'pumpprimer' grants to projects in their early stages. A further aim is to give preference to projects showing innovation in the field of prehistory research and to those scholars in the earliest stages of their research careers.

Level of Study: Unrestricted 
Type: Award

Value: $£ 100-£ 1,500$ per award

Frequency: Annual

Application Procedure: Applications will only be considered from members of the society.

Closing Date: 31 January

Funding: Private

Additional Information: www.prehistoricsociety.org/grants/ research_fund/

\section{For further information contact:}

Administrative Assistant, Prehistoric Society, Institute of Archaeology, 31-34 Gordon Square, London, WC1H 0PY, UK.

Email: prehistoric@ucl.ac.uk

\section{The John and Bryony Coles Bursary (Student Travel Award)}

Eligibility: Applicants must be registered students of archaeology (either part or full time) in the later stages of undergraduate study or in the early years of postgraduate study, or other equivalent status, without restriction on age. All applicants must provide proof of their student status (i.e. a letter from their institution). Student cards will not be accepted.

Level of Study: Unrestricted

Type: Award

Value: $£ 200$ and $£ 300$ each are usually given each year

Frequency: Annual

Application Procedure: Applications will only be considered from members of the society.

Closing Date: 31 January

Funding: Private

Additional Information: www.prehistoricsociety.org/grants/ the_john_and_bryony_coles_bursary_student_travel_award/

\section{For further information contact:}

Administrative Assistant, Prehistoric Society, Institute of Archaeology, 31-34 Gordon Square, London, WC1H 0PY, UK.

Email: prehistoric@ucl.ac.uk

\section{President's Commission on White House Fellowships}

O.P.M-Sheila Coates, 1900 E.Street, NW, Room B431, Washington, DC 20415, United States of America.
Tel: (1) 2023954522

Email: comments@whitehouse.gov

Website: www.whitehouse.gov/fellows

Contact: White House Fellowships

\section{White House Fellowships}

Purpose: To offer exceptional young men and women firsthanded experience working at the highest levels of the federal government

Eligibility: Civilian employees of the Federal government are not eligible

Level of Study: Postgraduate

Type: Fellowship

Value: A full-time, paid assistantship to the Vice President, Cabinet Securities, and other top-ranking government officials Length of Study: 1 year

Frequency: Annual

Study Establishment: The White House

Country of Study: United States of America

Application Procedure: Application instructions are available on the website

Closing Date: 1 February

Additional Information: Please check website for more details www.whitehouse.gov/get-involved/fellows/

\section{For further information contact:}

Email: whitehousefellows@who.eop.gov

\section{Prime Minister's Research Fellowship}

Indian Institute of Technology Hyderabad, Kandi, Sangareddy, Telangana 502285, India.

Contact: The Prime Minister's Research Fellowship

The Government of India is offering Prime Minister's Research Fellowship Scheme for Doctoral Studies (PhD) in IITs and IISc aimed at attracting the best talent.

\section{Prime Minister's Research Fellowship Scheme}

Purpose: The Prime Minister's Research Fellowship (PMRF) scheme is aimed at attracting the talent pool of the country to doctoral $(\mathrm{PhD})$ programs of Indian Institutes of Technology (IITs) and Indian Institute of Science (IISc) for carrying out research in cutting-edge science and technology domains, with focus on national priorities 
Eligibility: Citizens of India are eligible to apply. The candidate should have a very good command of English language. Therefore, the application should be written in English

Value: Applicants who fulfill the eligibility criteria, and are finally selected through a selection process, will be offered admission to $\mathrm{PhD}$ program in one of IITs/IISc with a fellowship of ₹70,000/- per month for the first two years, ₹75,000/- per month for the 3rd year, and ₹80,000/- per month in the 4th and 5th years. Apart from this, a research grant of ₹2.00 lakh per year will be provided to each of the Fellows for a period of 5 years to cover their academic contingency expenses and for foreign/national travel expenses

Country of Study: Any country

Application Procedure: Apply online

Closing Date: 30 September

Additional Information: For more details please visit the website scholarship-positions.com/prime-minister-researchfellowship/2018/02/27/ vikaspedia.in/education/career-gui dance/scholarships/prime-minister2019s-research-fellowship

\section{For further information contact:}

Email: support@pmrf2018.iith.ac.in

\section{Prince Charles Hospital Foundation's}

Rode Rd, Chermside West, QLD 4032, Australia.

Tel: (61) 393206888

Website: www.thecommongood.org.au

Contact: Prince Charles Hospital Foundation's

The Prince Charles Hospital is a major teaching hospital in Brisbane's northside with an emphasis in cardiac and respira- tory medicine and cardiothoracic surgery. It also has geriatric and rehabilitation services, elective orthopaedic services and cardiothoracic services, an inpatient psychiatric unit and a 16-bed palliative care unit.

\section{Prince Charles Hospital Foundation's PhD Scholarship}

Purpose: The aim of the scholarship is to support educational academic research and high-quality research training at TPCH or in the significant partnership with TPCH and its associated community programs. The scholarship provides the applicant with a living stipend to undertake research at or in significant association with, The Prince Charles Hospital

Eligibility: Applicants from Australia are eligible to apply for the scholarship. Applicants must be enrolled, or soon to be enrolled, full-time in a $\mathrm{PhD}$ program at an Australian University

Value: The scholarship will be valued at AU\$27,082 per annum. The scholarship provides the applicant with a living stipend to undertake research at or insignificant association with, The Prince Charles Hospital

Country of Study: Australia

Application Procedure: See the website

Closing Date: 23 January

Additional Information: For more details please visit the website scholarship-positions.com/prince-charles-hospitalfoundations-phd-scholarship-australia/2018/01/09/ www. studydriller.com/prince-charles-hospital-foundations-phd-scho larship-australia-2018/

\section{For further information contact:}

Email: Stephanie.Yerkovich@tpchfoundation.org.au 